\title{
Voltage-activated Calcium Currents in Octopus Cells of the Mouse Cochlear Nucleus
}

\author{
Ramazan Bal and Donata Oertel \\ ${ }^{1}$ Department of Biophysics, Faculty of Medicine, Firat University, 23119, Elazig, Turkey \\ ${ }^{2}$ Department of Physiology, University of Wisconsin Medical School, 1300 University Avenue, Madison, WI 53706, USA
}

Received: 6 April 2007; Accepted: 28 June 2007; Online publication: 21 August 2007

\begin{abstract}
Octopus cells, neurons in the most posterior and dorsal part of the mammalian ventral cochlear nucleus, convey the timing of synchronous firing of auditory nerve fibers to targets in the contralateral superior paraolivary nucleus and ventral nucleus of the lateral lemniscus. The low input resistances and short time constants at rest that arise from the partial activation of a large, low-voltage-activated $\mathrm{K}^{+}$conductance $\left(\mathrm{g}_{\mathrm{KL}}\right)$ and a large mixed-cation, hyperpolarization-activated conductance $\left(g_{\mathrm{h}}\right)$ enable octopus cells to detect coincident firing of auditory nerve fibers with exceptional temporal precision. Octopus cells fire conventional, $\mathrm{Na}^{+}$action potentials but a voltagesensitive $\mathrm{Ca}^{2+}$ conductance was also detected. In this study, we explore the nature of that calcium conductance under voltage-clamp. Currents, carried by $\mathrm{Ca}^{2+}$ or $\mathrm{Ba}^{2+}$ and blocked by $0.4 \mathrm{mM} \mathrm{Cd}^{2+}$, were activated by depolarizations positive to $-50 \mathrm{mV}$ and peaked at $-23 \mathrm{mV}$. At $-23 \mathrm{mV}$ they reached $1.1 \pm 0.1 \mathrm{nA}$ in the presence of $5 \mathrm{mM} \mathrm{Ca}^{2+}$ and $1.6 \pm 0.1 \mathrm{nA}$ in $5 \mathrm{mM} \mathrm{Ba}^{2+}$. Ten micromolar BAY K 8644, an agonist of highvoltage-activated L-type channels, enhanced $\mathrm{I}_{\mathrm{Ba}}$ by $63 \pm 11 \%(n=8)$ and $150 \mu \mathrm{M}$ nifedipine, an antagonist of L-type channels, reduced the $\mathrm{I}_{\mathrm{Ba}}$ by $65 \pm 5 \% \quad(n=5)$. Meanwhile, $0.5 \mu \mathrm{M} \omega$-Agatoxin IVA, an antagonist of $\mathrm{P} / \mathrm{Q}$-type channels, or $1 \mu \mathrm{M}$ w-conotoxin GVIA, an antagonist of N-type channels, suppressed $\mathrm{I}_{\mathrm{Ba}}$ by $15 \pm 4 \%(n=5)$ and $9 \pm 4 \% \quad(n=5)$, respectively. On average $16 \%$ of the current remained in the presence of the cocktail of blockers, indicative of the presence
\end{abstract}

Correspondence to: Donata Oertel - Department of Physiology · University of Wisconsin Medical School 1300 University Avenue, Madison, WI 53706, USA. Telephone: +1-608-2636281; fax: +1-6082623101; email: oertel@physiology.wisc.edu of R-type channels. Together these experiments show that octopus cells have a depolarization-sensitive $\mathrm{g}_{\mathrm{Ca}}$ that is largely formed from L-type $\mathrm{Ca}^{2+}$ channels and that $\mathrm{P} / \mathrm{Q}-, \mathrm{N}$-, and R-type channels are expressed at lower levels in octopus cells.

Keywords: voltage-sensitive calcium channels, cochlear nucleus, hearing, patch clamp, brain slices

\section{INTRODUCTION}

Octopus cells are remarkable neurons. Their time constants are among the fastest that have been recorded in the mammalian nervous system. Low input resistances allow octopus cells to generate exceptionally small, brief, and sharply timed excitatory postsynaptic potentials (EPSPs). Octopus cells detect the coincidence of many small subthreshold synaptic inputs from individual auditory nerve fibers (Golding et al. 1995; Ferragamo and Oertel 2002; McGinley and Oertel 2006). The jitter in the timing of firing in response to sounds is less than $200 \mu \mathrm{s}$ (Oertel et al. 2000). Octopus cells are exceptional not only in the temporal precision with which they encode acoustic information but also in the firing rates they can sustain. For example, in responses to periodic stimuli octopus cells can fire at every cycle to about $800 \mathrm{~Hz}$ (Rhode and Smith 1986).

To understand how octopus cells can signal with such temporal precision, we have undertaken a study of their biophysical characteristics. Whole-cell patch recordings in the current-clamp mode from cell bodies revealed that octopus cells have exceptionally strong hyperpolarization-activated inward and repolarizing outward currents as well as $\mathrm{Ca}^{2+}$-dependent 
and $\mathrm{Na}^{+}$-dependent, tetrodotoxin (TTX)-sensitive action potentials (Golding et al. 1999). The hyperpolarization-activated mixed cation conductance, $\mathrm{g}_{\mathrm{h}}$, and the low-voltage- and high-voltage-activated $\mathrm{K}^{+}$ conductances, $\mathrm{g}_{\mathrm{KL}}$ and $\mathrm{g}_{\mathrm{KH}}$, were studied under voltage-clamp (Bal and Oertel 2000; Bal and Oertel 2001). The TTX-sensitive inward current, however, was generally not possible to clamp; in the absence of TTX, depolarizing voltage pulses produce escaped action potentials. The low-voltage-activated, repolarizing $\mathrm{K}^{+}$conductance that is partially activated at rest makes octopus cells sensitive to the rate at which they are depolarized (Ferragamo and Oertel 2002). The present study is of the depolarization-activated $\mathrm{Ca}^{2+}$ inward current under voltage-clamp.

Voltage-dependent $\mathrm{Ca}^{2+}$ channels fall into three families that differ in the voltage range of activation, the rate at which they deactivate; in the voltage range, rate, and extent of inactivation; and in their sensitivity to pharmacological agents (Tsien et al. 1988; Bean 1989; Hille 2001). Most L-type calcium channels that are encoded by genes in the $\mathrm{Ca}_{V} 1$ family are activated by large depolarizations, more positive than $-30 \mathrm{mV}$; $\mathrm{Ca}_{\mathrm{V}} 1.3 \alpha$ channels are exceptional in that they are activated by lower voltages, positive to $-65 \mathrm{mV}$ ( $\mathrm{Xu}$ and Lipscombe 2001; Lipscombe et al. 2004). L-type channels are sensitive to dihydropyridines. They are enhanced by the dihydropyridine agonist, BAY K 8644, and blocked by the antagonist, nifedipine (Fox et al. 1987b; Carbone and Swandulla 1989). The sensitivity to dihydropyridine antagonists varies over an order of magnitude, however (Kanngiesser et al. 1988; Xu and Lipscombe 2001). P/Q-, N-, R-type channels are encoded by $\mathrm{Ca}_{\mathrm{V}} 2.1,2.2$, and 2.3, respectively. $\mathrm{P} / \mathrm{Q}-$ and $\mathrm{N}$-type calcium channels are sensitive to $\omega$ agatoxin IVA and $\omega$-conotoxin GVIA, respectively (McCleskey et al. 1987; Mintz et al. 1992; Boland et al. 1994; Overholt and Prabhakar 1997; MartinezPinna et al. 2002). P/Q- and N-type channels are activated by large depolarizations and inactivate rapidly but only partially. The R-type current requires large depolarizations, is insensitive to dihydropyridines, $\omega$-agatoxin, and $\omega$-conotoxin, and is rapidly inactivating (Randall and Tsien 1995). The lowvoltage-activated T-type channels are encoded by genes in the $\mathrm{Ca}_{\mathrm{V}} 3$ family and inactivate rapidly and completely. Diversity in voltage-gated $\mathrm{Ca}^{2+}$ channels arises not only from their being encoded by various families of genes but also because the transcripts from those genes have numerous alternatively spliced forms (Lipscombe et al. 2002).

The results of this study demonstrate that L-type $\mathrm{Ca}^{2+}$ channels predominate in octopus cells. More than $60 \%$ of the current carried by $\mathrm{Ba}^{2+}$ is sensitive to blockers of L-type channels but N-, P/Q-, and R-type channels were also detected. What the role of the voltage-sensitive $\mathrm{Ca}^{2+}$ current is in octopus cells is not entirely clear; it might serve to monitor electrical activity in octopus cells and to regulate homeostatic mechanisms.

\section{METHODS}

\section{Brain slice preparation}

Coronal slices of the ventral cochlear nucleus (VCN) were prepared from mice (ICR strain) of between 17 and 19 postnatal days. The animals were decapitated and the head was immersed in normal physiological saline. After the removal of the brain from the skull, it was cut coronally at the midcollicular level. The rostral surface of the caudal part of the brain was mounted on a Teflon block with a cyanoacrylate glue (Superglue). Slices of $180 \mu \mathrm{m}$ in thickness were cut using an oscillating tissue slicer (Frederick Haer, Newbrunswick, ME, USA). Slices were transferred to a storage chamber containing fresh, oxygenated, physiological saline at $33^{\circ} \mathrm{C}$ to allow slices to recover for up to $2 \mathrm{~h}$. For recording, the slices were transferred to a chamber of about $0.3 \mathrm{ml}$ through which oxygenated saline was continuously perfused at about $5 \mathrm{ml} / \mathrm{min}$. The temperature was kept at $33^{\circ} \mathrm{C}$ with a custom-made feedback-controlled heater.

\section{Identification of octopus cells}

Cells in slices were visualized with differential interference contrast optics (Axioscope FS, Zeiss) through a $\times 63$ water immersion objective. Octopus cells were initially identified by their characteristic location in a triangular region of heavily myelinated fibers just ventral and caudal to the translucent granule cell layer that separates the ventral from the dorsal cochlear nucleus. Illumination under bright-field conditions with a field diaphragm that was minimally open made octopus cells appear bright among dark bundles of myelinated fibers. Their characteristic response pattern to injected hyperpolarizing and depolarizing current pulses was used to confirm the visual identification after breaking into octopus cells with patch electrodes (Golding et al. 1995; Golding et al. 1999; Bal and Oertel 2000; Bal and Oertel 2001).

\section{Solutions and drugs}

The normal physiological saline contained (in $\mathrm{mM}$ ): $130 \mathrm{NaCl}, 3 \mathrm{KCl}, 1.2 \mathrm{KH}_{2} \mathrm{PO}_{4}, 2.4 \mathrm{CaCl}_{2}, 1.3 \mathrm{MgSO}_{4}$, $20 \mathrm{NaHCO}_{3}, 3$ HEPES, 10 glucose, saturated with $95 \% \mathrm{O}_{2} / 5 \% \mathrm{CO}_{2}, \mathrm{pH} 7.4$, between 25 and $31^{\circ} \mathrm{C}(\mathrm{Bal}$ and Oertel 2000; Bal and Oertel 2001). Normal 
physiological saline was used for preparation and incubation of slices. In current-clamp experiments involving the use of $\mathrm{Cd}^{2+}$, the external solution contained (in $\mathrm{mM}$ ): $138 \mathrm{NaCl}, 3 \mathrm{KCl}, 2.4 \mathrm{CaCl}_{2}, 1.3$ $\mathrm{MgCl}_{2}, 10$ HEPES, 10 glucose, $\mathrm{pH}$ 7.4. To study $\mathrm{Ca}^{2+}$ conductances under voltage clamp, they were separated from other conductances pharmacologically. The extracellular solution under "control" conditions contained (in $\mathrm{mM}$ ): 135 tetraethylammonium (TEA) chloride; $10 \mathrm{CsCl}, 10$ 4-aminopyridine (4-AP), $5 \mathrm{CaCl}_{2}$ or $5 \mathrm{BaCl}_{2}, 10$ HEPES, 10 glucose, $1 \mu \mathrm{M}$ TTX, $40 \mu \mathrm{M}$ 6,7-dinitroquinoxaline-2,3-dione (DNQX), $\mathrm{pH}$ 7.4. For measurements of barium currents through calcium channels, $\mathrm{CaCl}_{2}$ was replaced by $\mathrm{BaCl}_{2}$ on an equimolar basis. Cesium was used to suppress the hyperpolarization-activated current, $\mathrm{I}_{\mathrm{h}}$ (Bal and Oertel 2000), TEA and 4-AP to block $\mathrm{K}^{+}$currents (Bal and Oertel 2001), $1 \mu \mathrm{M}$ TTX to block voltage-sensitive $\mathrm{Na}^{+}$ current (Golding et al. 1999), and $40 \mu \mathrm{M}$ DNQX to block synaptic currents (Tocris Cookson, UK). Test solutions were applied to the chamber by redirecting the flow of liquid through a system of tubing and valves.

To minimize the errors introduced by series resistance, only pipettes of low resistance (3-4 M $\Omega$ ) were used. They were pulled from borosilicate glass $(1.2 \mathrm{~mm}$ OD) and were filled with a solution that contained (in $\mathrm{mM}$ ): 110 potassium gluconate, 9 HEPES, 9 EGTA, $4.5 \mathrm{MgCl}_{2}, 14$ phosphocreatinine (Tris salt), 4 ATP (Na-salt), and 0.3 GTP (Tris salt); $\mathrm{pH}$ was adjusted to 7.4 with $\mathrm{KOH}$ (Forscher and Oxford 1985). TTX, $\alpha$-dentrotoxin ( $\alpha$-DTX), Bay K 8644, $\omega$-agatoxin IVA, and $\omega$-conotoxin GVIA were purchased from Alomone labs (Israel) and other chemicals were obtained from Sigma. Bay K 8644 and nifedipine were dissolved in dimethylsulfoxide (DMSO) to make stock solutions and stored in single-use-aliquots in the dark at $-20^{\circ} \mathrm{C}$. The final DMSO concentration was $0.01 \%$ and in separate control experiments was found to have no effect on the cells' calcium currents. TTX, $\alpha$-DTX, $\omega$-agatoxin IVA, and $\omega$-conotoxin GVIA were dissolved in distilled water to make stock solutions and stored in single-use-aliquots at $-20^{\circ} \mathrm{C}$. The doses were close to saturating for each of the calcium channel blockers.

\section{Whole-cell recordings and data acquisition}

Current- and voltage-clamp recordings were performed with standard whole-cell patch-clamp techniques using an Axopatch-200A amplifier. Data were low-pass-filtered at 5-10 kHz. Current and voltage records were sampled at $10-40 \mathrm{kHz}$ and were digitized online using a Digidata 1320 interface (Axon Instruments, Foster City, CA, USA) and fed both to a chart recorder and to an IBM-compatible personal computer for storage and further analyses. Stimulus generation, data acquisition, and offline analysis of digitized data were done using pClamp software (version 8.03; Axon Instruments). After the formation of high-resistance seals (>1G $\Omega$ ) negative pressure was applied to obtain the whole-cell configuration. Series resistance varied from 6 to $15 \mathrm{M} \Omega$. All reported results were from recordings in which approximately $85-90 \%$ of the series resistance could be compensated on line. All recordings have been compensated for a junction potential of $-12 \mathrm{mV}$. Data are expressed as mean $\pm \mathrm{SE}$, with $n$ being the number of cells in which the measurement was made.

\section{RESULTS}

The present study is based on whole-cell recordings from 78 octopus cells that lasted between $20 \mathrm{~min}$ and $2 \mathrm{~h}$. The characteristics of octopus cells have been described in previous reports (Golding et al. 1999; Bal and Oertel 2000; Bal and Oertel 2001; Cao and Oertel 2005).

\section{Regenerative currents}

Action potentials measured at the cell body are small in octopus cells. From base to peak they are between 10 and $30 \mathrm{mV}$ (Golding et al. 1999; Ferragamo and Oertel 2002; Cao and Oertel 2005). The action potential in octopus cells is generated largely through TTX-sensitive $\mathrm{Na}^{+}$channels as illustrated in Figure 1. Under control conditions the octopus cell fired a single action potential at the onset of a depolarization, as is typical for octopus cells (Fig. 1A). The shape of the action potential can be seen more clearly at an expanded time scale in Figure 1B (thick trace, oblique arrow). Adding $50 \mathrm{nM} \alpha$-DTX to block $\mathrm{g}_{\mathrm{KL}}$ increased the input resistance so that the same current pulse produced a larger voltage change. This depolarization evoked not only a fast spike but also slower voltage oscillations (Fig. 1A, asterisks). The first oscillation had a complex shape, comprising an early, fast peak (Fig. 1B, downward arrow) and a later, slower but larger peak (Fig. 1B, asterisks). The further addition of $1 \mu \mathrm{M}$ TTX eliminated the early, fast component, slowed the development of the first of the slower voltage oscillations but did not affect their amplitude (Fig. 1A, B, asterisks). These traces show that the early, fast component of the action potential is mediated by a regenerative $\mathrm{Na}^{+}$current and confirm the earlier finding that action potentials in octopus cells are conventional (Golding et al. 1999). Presumably the action potential is generated at a site that is electrotonically distant from the cell body where the recording is made. The TTX-resistant 

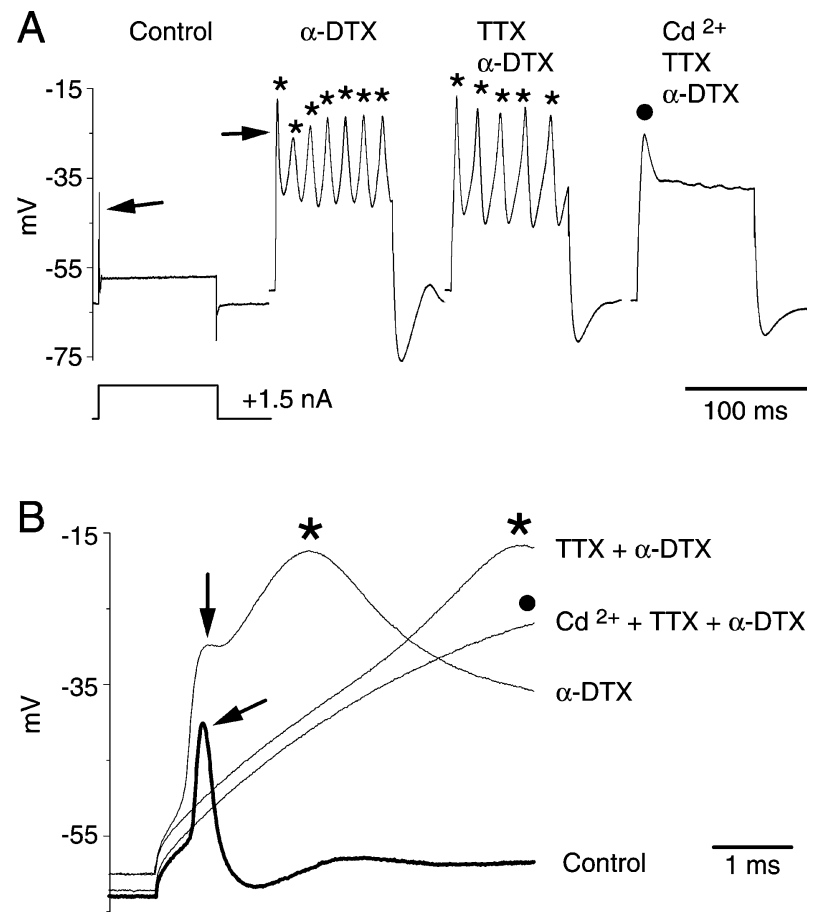

FIG. 1. Calcium spikes can be recorded in octopus cells. A A depolarizing pulse of current (1.5 nA) evoked a rapid action potential (leftward arrow) at its onset. After the application of $50 \mathrm{nM} \alpha$-DTX, a similar current pulse evoked an initial fast action potential (rightward arrow) that was followed by a train of slow ones (asterisks). The additional application of $1 \mu \mathrm{M}$ TTX removed the first, rapid spike but left the slower, later ones. Sensitivity to TTX showed that the first spike was mediated by the entry of $\mathrm{Na}^{+}$. The further addition of $0.2 \mathrm{mM} \mathrm{Cd}^{2+}$ abolished the slow spikes, leaving only an onset transient (filled circle). Sensitivity of the slow spikes to $\mathrm{Cd}^{2+}$ indicates that they were mediated through voltage-gated $\mathrm{Ca}^{2+}$ channels. B Expanded traces of the onset of the depolarizations in subpanel A show the time course of the first spikes. Under control conditions, the action potential in octopus cells is small and brief (thick trace, oblique arrow). $\alpha$-DTX, which blocks the low-voltageactivated repolarizing $\mathrm{K}^{+}$conductance, allows the peak of the sodium spike to rise to a more depolarized level (downward arrow) and triggers a slower but larger action potential (asterisks). The small, fast action potential is removed by TTX. The large, slow, action potential is sensitive to $\mathrm{Cd}^{2+}$. The depolarizing peak that is insensitive to $\mathrm{Cd}^{2+}$, TTX, and $\alpha$-DTX (filled circle) lacks an inflection and is not regenerative.

voltage oscillations had inflections on their rising phases that were an indication of the regenerative nature of the currents that produced them. The slow action potentials were abolished by the application of $0.2 \mathrm{mM} \mathrm{Cd}^{2+}$, indicating that they were produced by regenerative $\mathrm{Ca}^{2+}$ currents (Golding et al. 1999; Bal and Oertel 2001). In the absence of the current, the rise in the depolarization was slower and the peak depolarization was lower (Fig. 1A, B, dot). The voltage peak that was resistant to both TTX and $\mathrm{Cd}^{2+}$ showed no inflection, suggesting that it was produced by the delayed activation of the cell's $\mathrm{g}_{\mathrm{KH}}$ that repolarized the cell after the initial depolariza- tion. The following experiments explore the properties of the voltage-sensitive $\mathrm{Ca}^{2+}$ conductance.

\section{Voltage dependence of activation}

Unlike $\mathrm{I}_{\mathrm{h}}, \mathrm{I}_{\mathrm{KL}}$, and $\mathrm{I}_{\mathrm{KH}}, \mathrm{I}_{\mathrm{Ca}}$ was small in octopus cells. To resolve these currents, the extracellular solution contained relatively high concentrations of blockers of other currents. Under control conditions the bath contained $135 \mathrm{mM}$ TEA and $10 \mathrm{mM}$ 4-AP to block $\mathrm{I}_{\mathrm{KL}}$ and $\mathrm{I}_{\mathrm{KH}}, 10 \mathrm{mM} \mathrm{Cs}^{+}$to block $\mathrm{I}_{\mathrm{h}}, 1 \mu \mathrm{M}$ TTX to block $\mathrm{I}_{\mathrm{Na}}$, and $40 \mu \mathrm{M}$ DNQX to block spontaneous excitatory synaptic currents in all voltage-clamp measurements. Depolarizing steps from $-70 \mathrm{mV}$ (in some experiments from $-92 \mathrm{mV}$ ) evoked inward currents of about $1 \mathrm{nA}$ that were sensitive to $0.4 \mathrm{mM} \mathrm{Cd}^{2+}$ (Fig. 2A). The calcium current showed partial inactivation and was more prominent in some than in other octopus cells. Deactivation after the end of the depolarization required roughly $50 \mathrm{~ms}$ and had a $\tau \sim 4 \mathrm{~ms} ; 0.4 \mathrm{mM}$ $\mathrm{Cd}^{2+}$ reversibly abolished the inward current $(n=33)$ (Fig. 2A). $\mathrm{I}_{\mathrm{Ca}}$ was defined to be the difference between currents measured under control conditions and after the additional application of $0.4 \mathrm{mM} \mathrm{Cd}^{2+}$. By using the difference current to define $\mathrm{I}_{\mathrm{Ca}}$, contamination by any unblocked $\mathrm{K}^{+}$conductances and leak conductances was minimized. The voltage sensitivity of $\mathrm{I}_{\mathrm{Ca}}$ is revealed in the plot of the peak currents as a function of voltage (Fig. 2B, filled circle). $\mathrm{I}_{\mathrm{Ca}}$ began to activate at potentials above $-50 \mathrm{mV}$, reached a maximal amplitude of $1.1 \pm 0.1 \mathrm{nA}$ at $-23 \mathrm{mV}(n=5)$, and became smaller with progressively stronger depolarizing voltage steps. These results indicate that the inward current observed under our recording conditions was carried mainly by $\mathrm{Ca}^{2+}$ ions through high-voltageactivated $\mathrm{Ca}^{2+}$ channels.

Also in contrast with $\mathrm{I}_{\mathrm{h}}, \mathrm{I}_{\mathrm{KL}}$, and $\mathrm{I}_{\mathrm{KH}}, \mathrm{I}_{\mathrm{Ca}}$ was difficult to clamp even when other conductances were largely blocked. Good voltage control of calcium currents was obtained from only about one in ten recorded octopus cells. Figure 2A, B shows an example of an octopus cell in which $\mathrm{I}_{\mathrm{Ca}}$ could be clamped; in this cell the peak inward current rose gradually over a range of depolarizing voltage steps. Figure 2C, D shows two recordings from octopus cells in which calcium currents could not be clamped. In these cells the allor-none current peaks were indicative of escaped action potentials. Figure 2C illustrates how step depolarization to levels more positive than $-45 \mathrm{mV}$ evoked obviously escaped action potentials. The I/V plot in Figure 2D shows that the peak inward current rose in an all-or-none step, also at $-45 \mathrm{mV}$. Escape from voltage control could have arisen from imperfect space-clamp or from a voltage-clamp that was slow relative to the kinetics of the current or probably from a combination of the two factors. Octopus cells have 


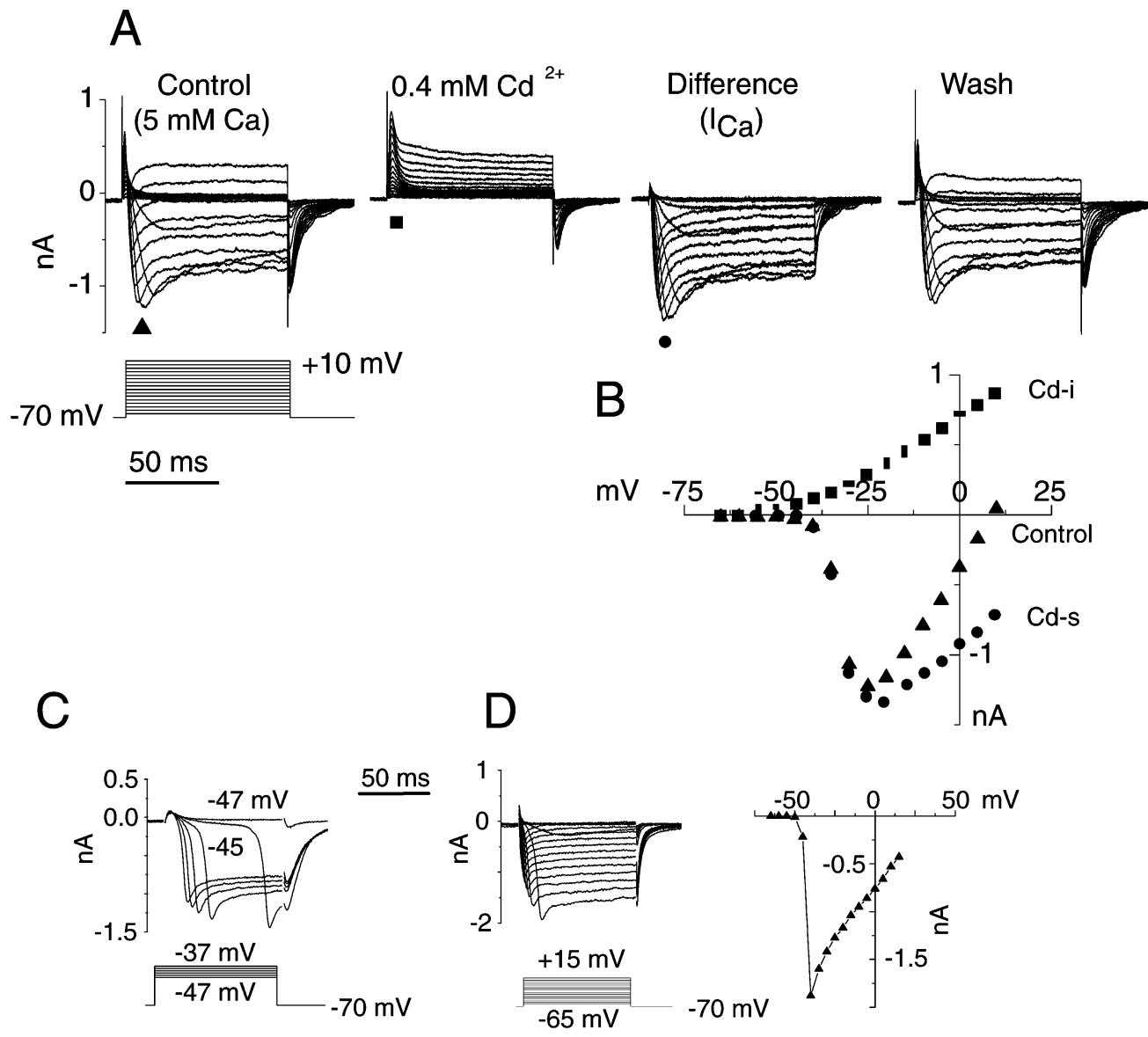

FIG. 2. The voltage-dependent inward $\mathrm{Ca}^{2+}$ current, $\mathrm{I}_{\mathrm{Ca}}$, is defined by its sensitivity to extracellular $\mathrm{Cd}^{2+}$. A Depolarizing voltage pulses in $5 \mathrm{mV}$ steps evoked voltage-sensitive inward and outward currents (protocol is illustrated in the inset). The addition of $0.4 \mathrm{mM} \mathrm{Cd}^{2+}$ blocked the inward current. The $\mathrm{I}_{\mathrm{Ca}}$, obtained by digitally subtracting the traces recorded in the presence of $\mathrm{Cd}^{2+}$ from those under control conditions, was entirely inward. The block of current by $\mathrm{Cd}^{2+}$ was reversible. B: I/V relationships for the current traces in subpanel $\mathbf{A}$, as indicated by the symbols. The peak inward current under control conditions (filled triangle) activated positive to about $-40 \mathrm{mV}$ and peaked at about $-20 \mathrm{mV}$. The $\mathrm{Cd}^{2+}$-insensitive current was outward and activated at about $-40 \mathrm{mV}$, indicating that it is high-voltageactivated (filled square, $\mathrm{Cd}-\mathrm{i}$ ). The $\mathrm{Cd}^{2+}$-sensitive current was inward

dendrites that are about one length constant long (McGinley et al. 2005). They also have large axons with local collaterals and terminals whose position and length is variable (Golding et al. 1995). Anatomical labeling has shown that in many cases the axons of octopus cells are cut close to the cell body and lack axon terminals (Oertel et al. 1990; Golding et al. 1995). If all $\mathrm{g}_{\mathrm{Ca}}$ were in terminals, we would have expected some octopus cells to have little or no $\mathrm{g}_{\mathrm{Ca}}$ but that was not the case; every cell we tested had $\mathrm{g}_{\mathrm{Ca}}$. We conclude, therefore, that at least some $\mathrm{g}_{\mathrm{Ca}}$ is associated with the cell body and dendrites.

When $5 \mathrm{mM} \mathrm{Ba}^{2+}$ was substituted for $5 \mathrm{mM} \mathrm{Ca}^{2+}$, inward currents were also observed (Fig. 3A). Like currents carried by $\mathrm{Ca}^{2+}$, inward currents in the (filled circle, $\mathrm{Cd}$-s). The measurements were made in the presence of $135 \mathrm{mM}$ TEA, $10 \mathrm{mM}$ 4-AP, and $10 \mathrm{mM} \mathrm{Cs}^{+}$to reduce $\mathrm{g}_{\mathrm{KH}}, \mathrm{g}_{\mathrm{KL}}$, and $\mathrm{g}_{\mathrm{h}}$. C A family of traces showing unclamped currents in an octopus cell. The cell body was depolarized from $-70 \mathrm{mV}$ to between -47 and $-37 \mathrm{mV}$ in $2-\mathrm{mV}$ steps. A breakaway spike occurred with a depolarization at the cell body to $-45 \mathrm{mV}$. As in current-clamp, a small depolarization evoked an action potential after a delay and the delay became shorter with increasing depolarizations. D A family of traces from another neuron with poor voltage control. The I/V plot for the current traces shows that the inward current seemed to increase in a step. Such step increases are indicative of the generation of an escaped action potential.

presence of $\mathrm{Ba}^{2+}$ were abolished in the presence of $0.4 \mathrm{mM} \mathrm{Cd}^{2+}$. The current carried by $\mathrm{Ba}^{2+}, \mathrm{I}_{\mathrm{Ba}}$, was defined as the $\mathrm{Cd}^{2+}$-sensitive difference current to minimize contamination through unblocked $\mathrm{K}^{+}$or leakage conductances. The voltage sensitivity of $\mathrm{I}_{\mathrm{Ba}}$ is illustrated in Figure 3B. The peaks of inward difference currents recorded when the extracellular saline contained $\mathrm{Ba}^{2+}, 1.6 \pm 0.1 \mathrm{nA}(n=10)$, were larger than those recorded in the presence of $\mathrm{Ca}^{2+}, 1.1 \pm 0.1 \mathrm{nA}$ $(n=5)$, but had a similar voltage sensitivity (Fig. 3D). The voltage sensitivity of $\mathrm{I}_{\mathrm{Ba}}$ in other cells (data not shown) is consistent with that of individual currents, suggesting that in a subpopulation of octopus cells, $\mathrm{I}_{\mathrm{Ba}}$ can consistently be quite well-clamped. The channels that mediate $\mathrm{I}_{\mathrm{Ba}}$ follow a pattern that is common 
A
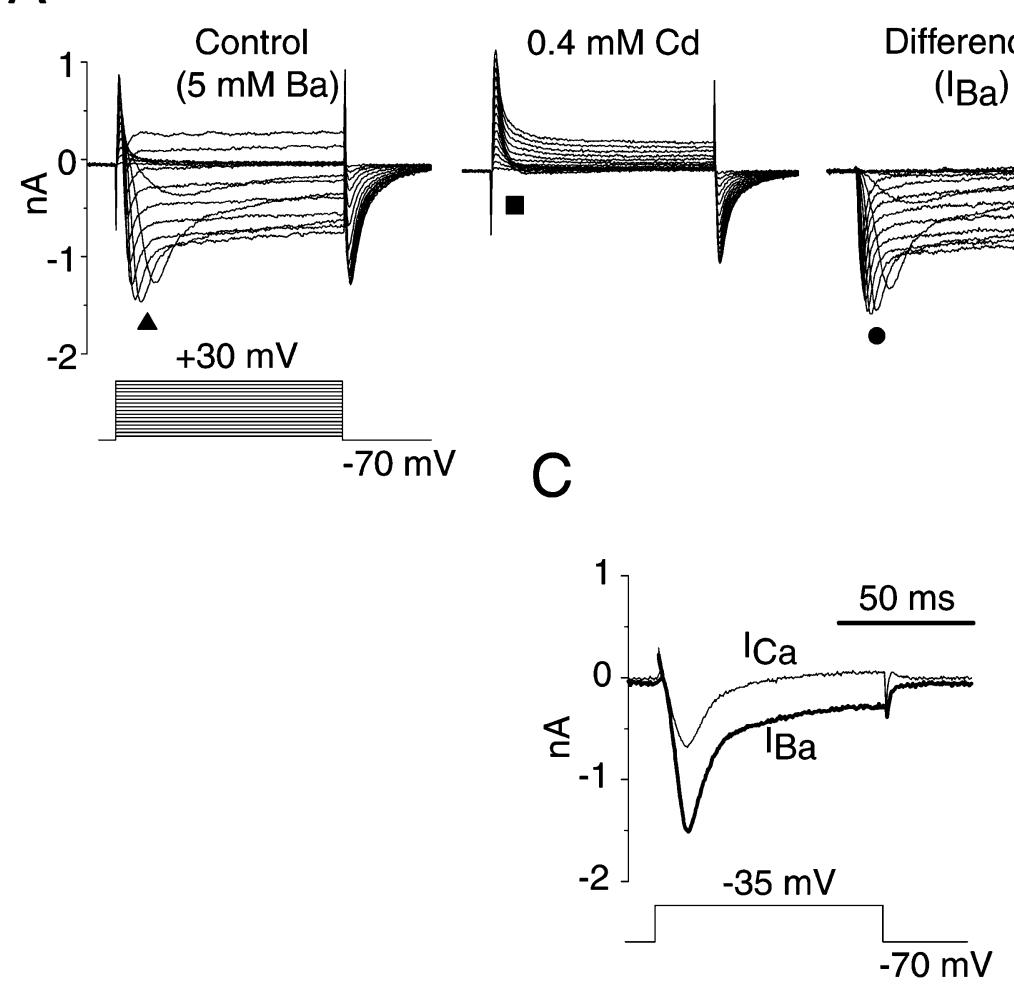

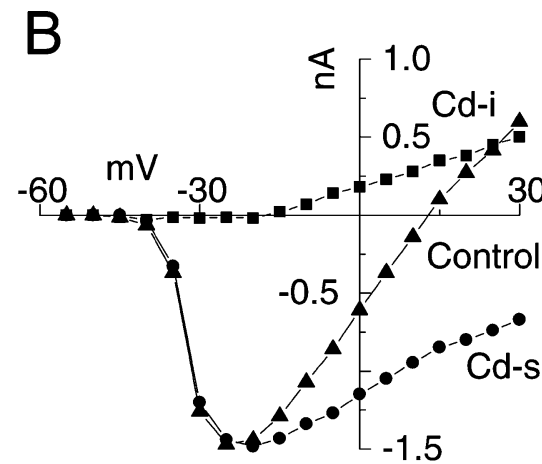

D

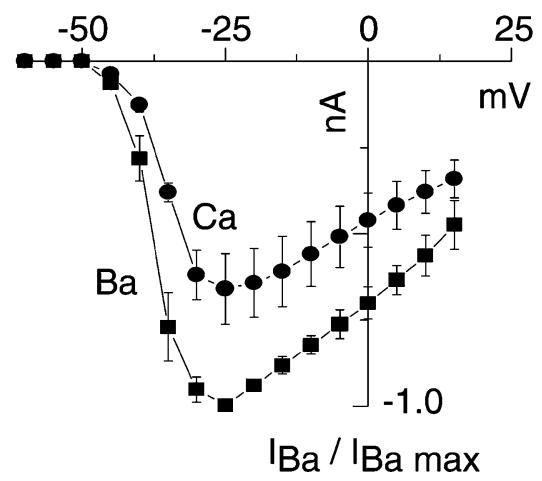

FIG. 3. Substitution of $\mathrm{Ba}^{2+}$ for $\mathrm{Ca}^{2+}$ as a charge carrier resulted in larger inward currents. A Depolarizing voltage steps between -70 and $+30 \mathrm{mV}$ evoked inward currents under control conditions that were blocked by $0.4 \mathrm{mM} \mathrm{Cd}^{2+}$. Digital subtraction of currents in the presence of $\mathrm{Cd}^{2+}$ from those under control conditions revealed I $\mathrm{Ba}$. B I/ $\checkmark$ plots of currents measured in subpanel $\mathbf{A}$ as indicated by the

among voltage-sensitive $\mathrm{Ca}^{2+}$ channels, in that they are more permeable to $\mathrm{Ba}^{2+}$ than to $\mathrm{Ca}^{2+}$ and that they show less inactivation in the presence of $\mathrm{Ba}^{2+}$ (Carbone and Lux 1987; Fox et al. 1987a). For two reasons most of the experiments described here measure $\mathrm{I}_{\mathrm{Ba}}$. First, the $\mathrm{Ba}^{2+}$ currents are larger and thus provide greater resolution and, second, the entry of $\mathrm{Ba}^{2+}$ does not activate opposing $\mathrm{Ca}^{2+}$-dependent $\mathrm{K}^{+}$currents. It has also been reported that $\mathrm{Ba}^{2+}$ minimizes the rundown of calcium currents (Wicher and Penzlin 1997; Scamps et al. 1998); indeed we did not observe rundown of $\mathrm{Ba}^{2+}$ currents.

\section{Voltage dependence of inactivation}

Presentation of long pulses reveals inactivation of $\mathrm{I}_{\mathrm{Ba}}$ (Fig. 4A). The voltage dependence of inactivation was examined by preceding a test pulse with a family of conditioning prepulses. The peak amplitude of the leak-subtracted inward current during the test pulse was normalized to the maximum current levels obtained after a maximally negative prepulse to $-100 \mathrm{mV}$, averaged in five cells and plotted as a function of the symbols. C Difference currents that are $I_{C a}$ and $I_{B a}$ in one cell show that $\mathrm{I}_{\mathrm{Ba}}$ is larger than $\mathrm{I}_{\mathrm{Ca}}$. Inward currents were measured first in the presence of $5 \mathrm{mM} \mathrm{Ca}^{2+}$, then after $5 \mathrm{mM} \mathrm{Ba}^{2+}$ had been substituted for the $\mathrm{Ca}^{2+}$ and finally after $0.4 \mathrm{mM} \mathrm{Cd}^{2+}$ was added. D Averaged I/V plot of the difference currents, $\mathrm{I}_{\mathrm{Ca}}$ and $\mathrm{I}_{\mathrm{Ba}}$, measured in three cells shows that $\mathrm{I}_{\mathrm{Ba}}$ is consistently larger than $\mathrm{I}_{\mathrm{Ca}}$.

conditioning potentials in Figure 4C. This relationship was fitted by the Boltzmann equation:

$$
I / I_{\max }=1 /\left(1+\exp \left[\left(V-V_{0.5}\right) / k\right]\right)
$$

where $I$ is the amplitude of the peak current at the onset of the test pulse, $I_{\max }$ is the maximum current obtained after the most hyperpolarizing conditioning pulse, $V$ is the potential of the conditioning pulse, $V_{0.5}$ is the conditioning prepulse potential at which the current is half-inactivated, and $k$ is the slope factor. The smooth curve in Fig. $4 \mathrm{C}$ has $V_{0.5}=$ $-46.6 \pm 1.1 \mathrm{mV}$ and $k=7.5 \pm 0.4 \mathrm{mV}, n=5$. The steadystate inactivation curve for the whole current is similar to that measured for other high-voltageactivated calcium currents, such as in mouse vestibular neurons (Desmadryl et al. 1997), rat trigeminal ganglion neurons (Ikeda and Matsumoto 2003), rat cerebellar granule neurons (Randall and Tsien 1995), and chick sensory neurons (Fox et al. 1987a). The steady-state voltage dependence of inactivation showed some deviation from a single 

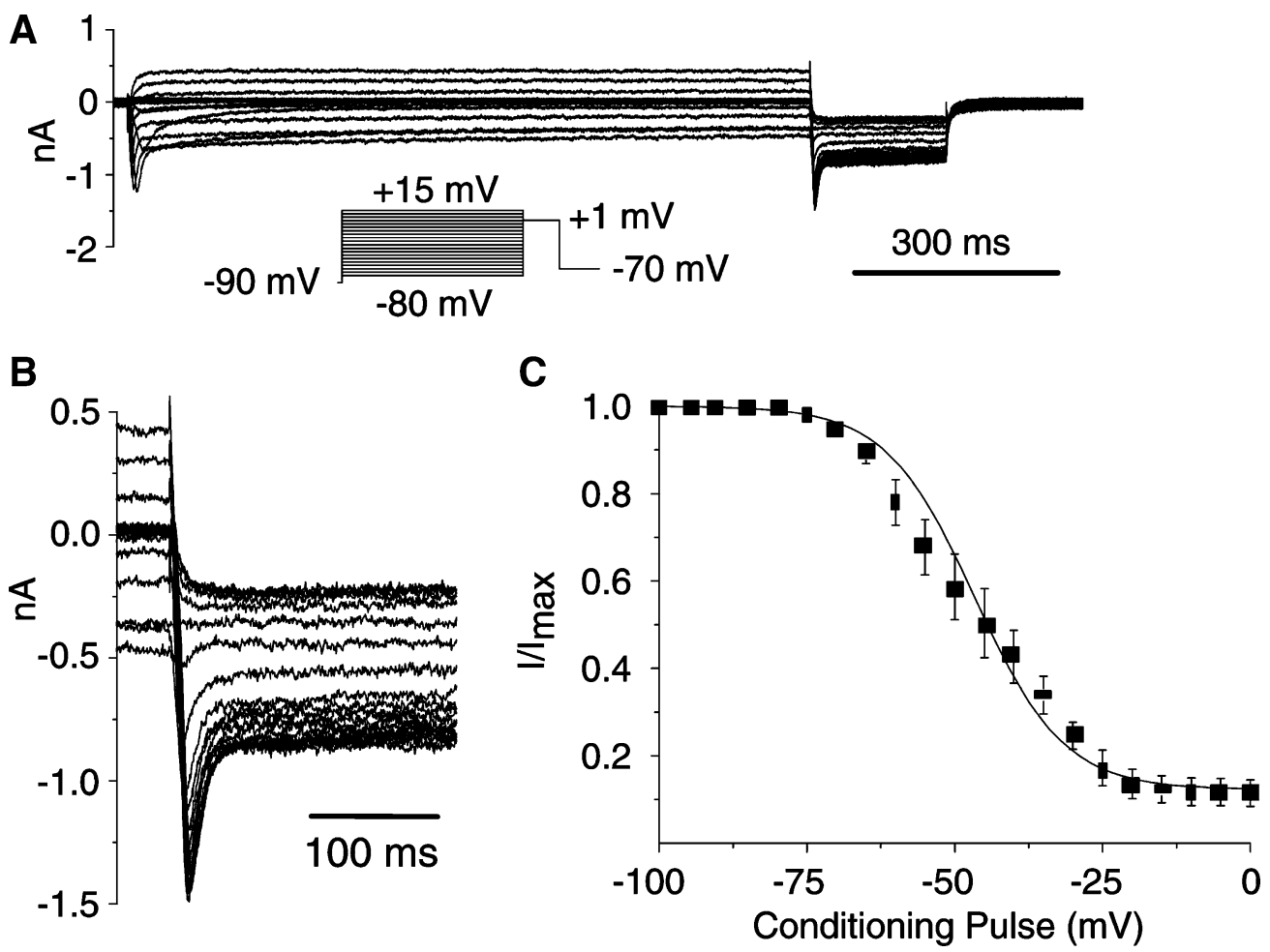

FIG. 4. The $\mathrm{Ba}^{2+}$ current inactivates. A Currents were evoked by a voltage protocol that is illustrated in the inset. Conditioning pulses between -80 and $+15 \mathrm{mV}$ in $5-\mathrm{mV}$ steps for 1,000 ms preceded a test pulse to $+1 \mathrm{mV}$ for $200 \mathrm{~ms}$. B Responses to the onset of test pulses to $+1 \mathrm{mV}$ in subpanel $\mathbf{A}$ are expanded. Peak inward currents were largest when the preceding conditioning pulse was most hyperpolarized. C

Boltzmann relationship. This deviation might have arisen from imperfect voltage-clamping; escaped depolarizing currents could have contributed to the current measured at depolarized potentials. It is also possible that $\mathrm{I}_{\mathrm{Ba}}$ might have consisted of multiple current components (Slesinger and Lansman 1991; Randall and Tsien 1995; Overholt and Prabhakar 1997). Note that with conditioning prepulse potentials more hyperpolarized than about $-70 \mathrm{mV}$ all inactivation was removed. For that reason in the majority of experiments, $\mathrm{I}_{\mathrm{Ca}}$ and $\mathrm{I}_{\mathrm{Ba}}$ were evoked from holding potentials of $-70 \mathrm{mV}$. At the resting potential of octopus cells, $-62 \mathrm{mV}, \mathrm{I}_{\mathrm{Ca}}$ was $5 \%$ inactivated.

An attempt was made to separate components of $\mathrm{I}_{\mathrm{Ba}}$ that might have inactivated more strongly from those that inactivated less strongly. A two-pulse protocol that was separated by a depolarized holding potential was used as illustrated in Figure 5A. First the neuron was depolarized to a range of potentials between -63 and $+12 \mathrm{mV}$, from a $-90-\mathrm{mV}$ holding potential, then the cell was held at $-40 \mathrm{mV}$ for $1 \mathrm{~s}$ and the test pulses were presented again. The currents evoked from a $-90-\mathrm{mV}$ holding potential comprised transient and sustained components (Fig. 5A, B). Those currents evoked from $-40 \mathrm{mV}$ had relatively
The peak amplitude of the leak-subtracted inward currents during the test pulse, plotted as a function of the potential of the preceding conditioning pulse, pooled from five octopus cells provides a measure of steady-state inactivation. The continuous line is the Boltzmann function with $V_{0.5}$ of $-46.6 \pm 1.1$ and $k$ of $7.5 \pm 0.4 \mathrm{mV}$.

smaller transient than sustained components (Fig. $5 \mathrm{~B})$ but there was no clear difference in the kinetics or voltage sensitivity between them (Fig. $5 \mathrm{C}$ ).

Octopus cells have little or no low-voltage-activated $\mathrm{Ca}^{2+}$ current. T-type currents activate at relatively hyperpolarized potentials, near $-70 \mathrm{mV}$, and are strongly inactivated; some L-type currents also activate at relatively hyperpolarized potentials (Xu and Lipscombe 2001). $\mathrm{I}_{\mathrm{Ba}}$ failed to activate between -70 and $-50 \mathrm{mV}$ even when the holding potential was $-90 \mathrm{mV}$, indicating that little, if any, of $\mathrm{I}_{\mathrm{Ba}}$ was mediated through low-voltage-activated L-type or T-type $\mathrm{Ca}^{2+}$ channels.

\section{Pharmacological properties}

To identify what type(s) of calcium channels underlies the macroscopic current, its sensitivity was tested to a variety of $\mathrm{Ca}^{2+}$ channel agonists and antagonists. As noted above, $\mathrm{I}_{\mathrm{Ca}}$ and $\mathrm{I}_{\mathrm{Ba}}$ in octopus cells were completely blocked by $0.4 \mathrm{mM} \mathrm{Cd}^{2+}$, a nonspecific calcium channel blocker (Figs. 2 and 3).

The presence of L-type $\mathrm{Ca}^{2+}$ channels was investigated using a dihydropyridine agonist and an antagonist (Fig. 6). The agonist of L-type calcium channels, $10 \mu \mathrm{M}$ BAY K 8644, enhanced $\mathrm{I}_{\mathrm{Ba}}$, and 

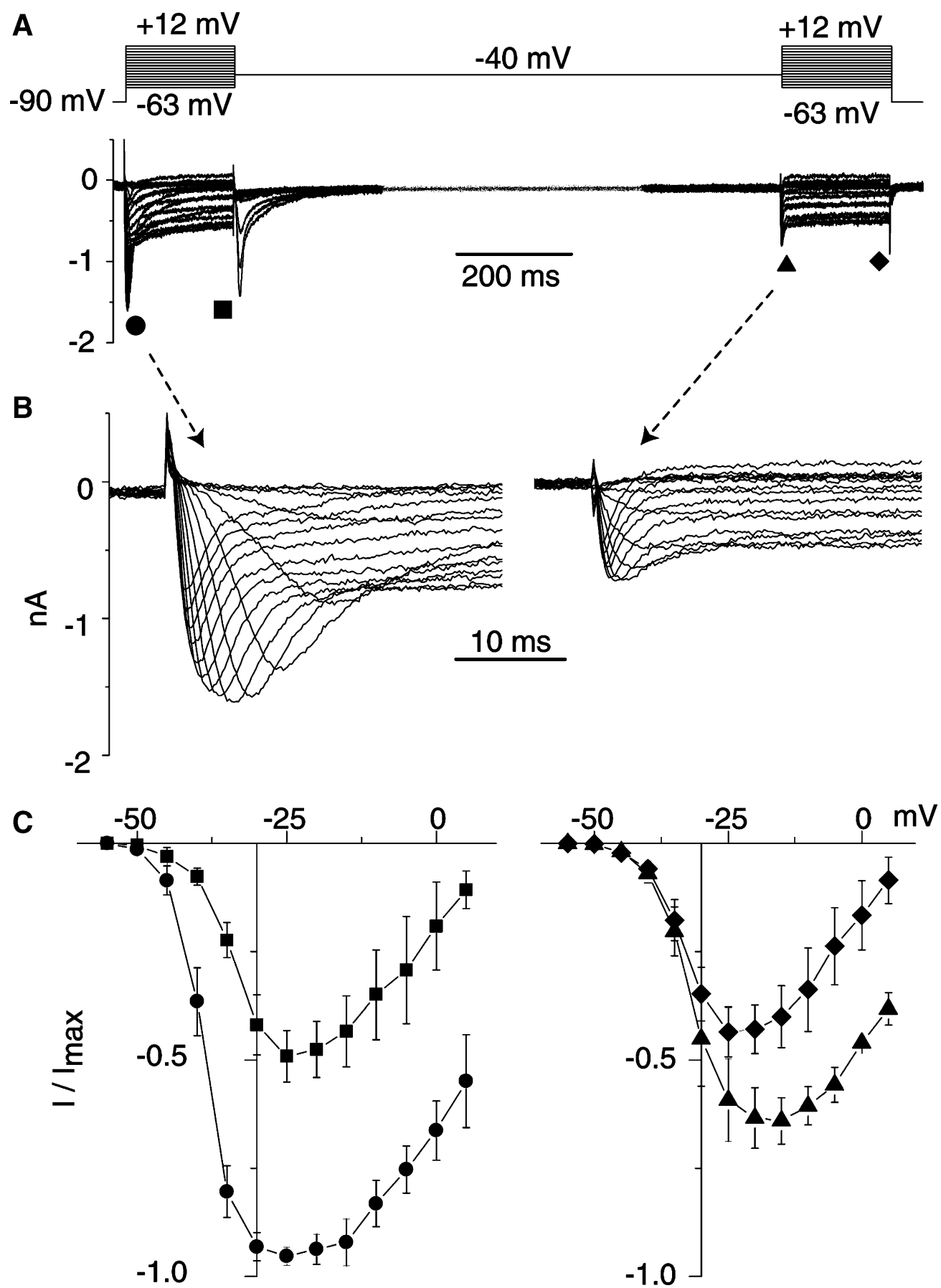

FIG. 5. Both transient and sustained components of the voltagesensitive $\mathrm{Ba}^{2+}$ current were larger when evoked after the cell was held at a negative holding potential. A The family of voltage pulses was first presented from a holding potential of $-90 \mathrm{mV}$ and then again after the cell had been held at $-40 \mathrm{mV}$ for $1 \mathrm{~s}$. Both the transient and sustained $\mathrm{Ba}^{2+}$ currents were larger when they followed a negative holding potential. B Expanded view of the families of currents evoked by

slowed deactivation as observed in other neurons (Fig. 6A) (Hess et al. 1984; Carbone and Swandulla 1989). At $-25 \mathrm{mV}$ the peak current was enhanced by $63 \pm 11 \%(n=8)$. In the presence of BAY K $8644, \mathrm{I}_{\mathrm{Ba}}$ also seemed to activate at more negative voltages but the presence of escaped $\mathrm{Ba}^{2+}$ currents could have depolarizing pulses after holding at $-90 \mathrm{mV}$ (left) and after holding at $-40 \mathrm{mV}$ (right). C The average I/V relationships evoked after holding at $-90 \mathrm{mV}$ for transient (filled circle) and sustained currents (filled square) and evoked after holding at $-40 \mathrm{mV}$ for transient (filled diamond), and sustained currents (filled triangle) in three cells. The peak transient was affected more strongly by holding potential than the steady-state $I_{\mathrm{Ba}}$.

contributed to the apparent shift in voltage sensitivity. The maximal effect of BAY K 8644 was observed 1 min after application and was largely reversible. Application of $150 \mu \mathrm{M}$ nifedipine, an antagonist of L-type $\mathrm{Ca}^{2+}$ channels, reduced $\mathrm{I}_{\mathrm{Ba}}$ by $65 \pm 5 \%$ ( $n=5$ ) (Fig. $6 \mathrm{~B}$ ). These results indicate that part of the macroscopic $\mathrm{Ca}^{2+}$ 
current in octopus cells entered through high-voltageactivated, L-type channels. Activation required depolarization above $-50 \mathrm{mV}$, as observed for L-type channels elsewhere (Regan et al. 1991; Desmadryl et al. 1997; Li et al. 1998; Bruehl and Wadman 1999; Luhmann et al. 2000; Hille 2001). The $\mathrm{I}_{\mathrm{Ba}}$ reached maximal amplitude at about $-23 \mathrm{mV}$, which is also within the range reported by others (Fox et al. 1987a; Mouginot et al. 1997).

$\mathrm{P} / \mathrm{Q}$ - and N-type calcium channels are sensitive to $\omega$ agatoxin IVA and $\omega$-conotoxin GVIA, respectively (McCleskey et al. 1987; Mintz et al. 1992; Boland et al. 1994). The peak $\mathrm{I}_{\mathrm{Ba}}$ was reduced by $15 \pm 4 \% \quad(n=5)$ by $0.5 \mu \mathrm{M} \omega$-agatoxin IVA (Fig. 6C). Application of $1 \mu \mathrm{M} \omega$-conotoxin GVIA reduced $\mathrm{I}_{\mathrm{Ba}}$ by $9 \pm 4 \% \quad(n=5)$ (Fig. 6D). These results indicate that $\mathrm{P} / \mathrm{Q}$ - and N-type channels each contribute a relatively small fraction of $\mathrm{g}_{\mathrm{Ca}}$. The currents that are sensitive to dihydropyridines, $\omega$-agatoxin IVA, and $\omega$-conotoxin GVIA begin to be activated at about $-50 \mathrm{mV}$ and peak near $-25 \mathrm{mV}$, as expected for high-voltage-activated $\mathrm{I}_{\mathrm{Ca}}$ (Fig. 6B-D).

Application of nifedipine, $\omega$-conotoxin, and $\omega$ agatoxin at saturating concentrations $(150,1$, and 0.5 $\mu \mathrm{M}$, respectively) together with $1 \mathrm{mM}$ amiloride, an antagonist of T-type calcium channels (Coste et al. 2007), left some of the control $\mathrm{I}_{\mathrm{Ba}}$ unblocked (Fig. 7). The residual current was variable and showed voltage sensitivity (Fig. 7B). This residual current resembled the R-type current described in central and peripheral neurons (Randall and Tsien 1995; Desmadryl et al. 1998).

\section{DISCUSSION}

Octopus cells possess voltage-sensitive $\mathrm{Ca}^{2+}$ currents. In current-clamp, Golding et al. (1999) showed that regenerative, $\mathrm{Ca}^{2+}$-mediated action potentials could be evoked in octopus cells when $\mathrm{Na}^{+}$and $\mathrm{K}^{+}$currents were blocked. Now under voltage-clamp we have shown that $\mathrm{Ca}^{2+}$ currents are mediated through several types of $\mathrm{Ca}^{2+}$ channels. The $\mathrm{Ca}^{2+}$ currents were activated by depolarizations to membrane potentials more positive than $-50 \mathrm{mV}$, indicating that they are high-voltage-activated. When measured in the presence of $5 \mathrm{mM}$ extracellular $\mathrm{Ca}^{2+}$, the peak current was about $1.1 \mathrm{nA}$ at $-23 \mathrm{mV}$; in the presence of $5 \mathrm{mM}$ extracellular $\mathrm{Ba}^{2+}$ the peak current was about $1.6 \mathrm{nA}$. The sensitivity of these currents to agonists and antagonists provided clues about the types of ion channels that mediate them. The sensitivity to BAY K 8644 and nifedipine indicates that about $65 \%$ of the conductance is through L-type $\mathrm{Ca}^{2+}$ channels. The sensitivities of $15 \%$ of $\mathrm{I}_{\mathrm{Ba}}$ to $0.5 \mu \mathrm{M}$ $\omega$-agatoxin IVA and $9 \%$ to $1 \mu \mathrm{M} \omega$-conotoxin GVIA indicate that a smaller proportion of the current was mediated through $\mathrm{P} / \mathrm{Q}$ - and N-type channels, respectively. The insensitivity of about $16 \%$ of the current to any of these blockers suggests that octopus cells also have R-type channels. In contrast to recordings of $\mathrm{I}_{\mathrm{KL}}$, $\mathrm{I}_{\mathrm{KH}}$, and $\mathrm{I}_{\mathrm{h}}$, which could be well clamped in most octopus cells, $\mathrm{I}_{\mathrm{Ca}}$ could be clamped in only about $10 \%$ of octopus cells. Either the $\mathrm{Ca}^{2+}$ conductances reside in regions of the cell that are electrically distant and/ or that the voltage clamp was not fast enough to clamp the rapid regenerative currents. Some of the current must have entered through the soma and/or dendrites, however, because $\mathrm{Ca}^{2+}$ currents were observed in every octopus cell and we know that axons of octopus cells in coronal slices are often cut near the soma (McGinley et al. 2005).

\section{Functional role of voltage-sensitive calcium currents in signaling by octopus cells}

There are about 200 octopus cells in each posterior VCN of a mouse (Osen 1969; Willott and Bross 1990) that project contralaterally through the intermediate acoustic stria to the superior paraolivary nucleus and to the ventral nucleus of the lateral lemniscus (Warr 1969; Smith et al. 1993; Schofield 1995; Adams 1997; Vater et al. 1997). The pathway through octopus cells may be involved in the analysis of temporal features of signals for the recognition of natural sounds (Covey and Casseday 1991; Oertel and Wickesberg 2002). Octopus cells are broadly tuned and are driven at the onset of tones and noise and by click trains (Godfrey et al. 1975; Rhode et al. 1983; Rhode and Smith 1986; Oertel et al. 2000; Smith et al. 2005). Of all cell types in the VCN, they respond with the strongest synchronization to amplitude-modulated sounds and to simple speech sounds (Rhode 1994; Rhode 1998). The jitter in the timing of firing in response to trains of clicks is less than $200 \mu$ s (Oertel et al. 2000). In responses to periodic stimuli octopus cells can fire at every cycle to about $800 \mathrm{~Hz}$ (Rhode and Smith 1986).

Octopus cells detect synchronous firing among auditory nerve fibers and convey its occurrence with action potentials that are generated with temporal precision (Golding et al. 1995; Oertel et al. 2000; Ferragamo and Oertel 2002; McGinley and Oertel 2006). Two opposing voltage-sensitive conductances, $\mathrm{g}_{\mathrm{KL}}$ and $\mathrm{g}_{\mathrm{h}}$, are activated at rest and endow octopus cells with low input resistances (6 M $\Omega$ ), short time constants $(\sim 200 \mu \mathrm{s})$, and consequently brief EPSPs ( $\sim 1$ ms) (Golding et al. 1995; Gardner et al. 1999; Bal and Oertel 2000; Bal and Oertel 2001; Gardner et al. 2001; Cao and Oertel 2005). Sensitivity to the rate of depolarization requires that EPSPs sum on their rising phases and make coincidence detection yet sharper (Ferragamo and Oertel 2002; McGinley 
A

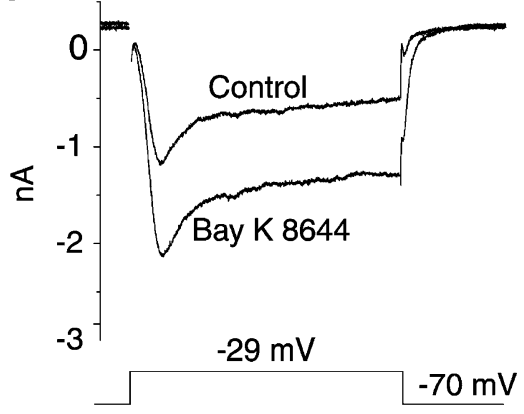

B

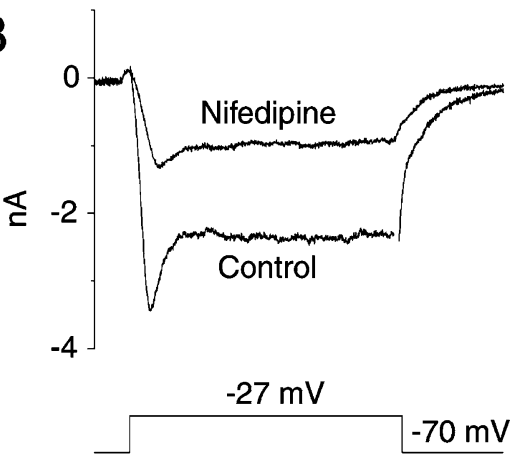

C

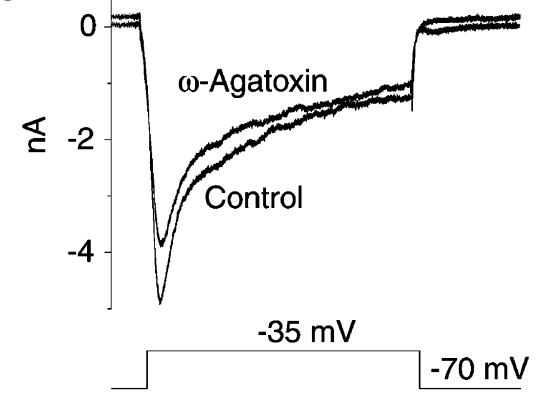

D

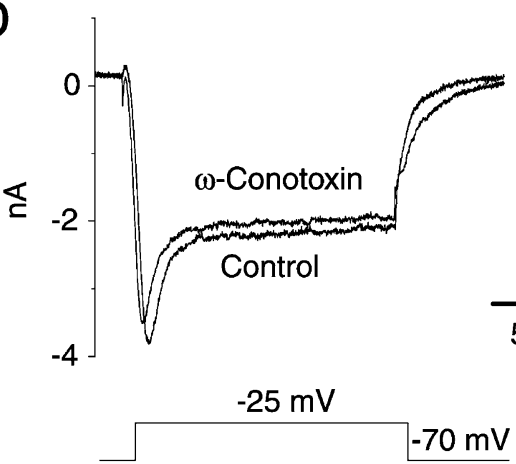

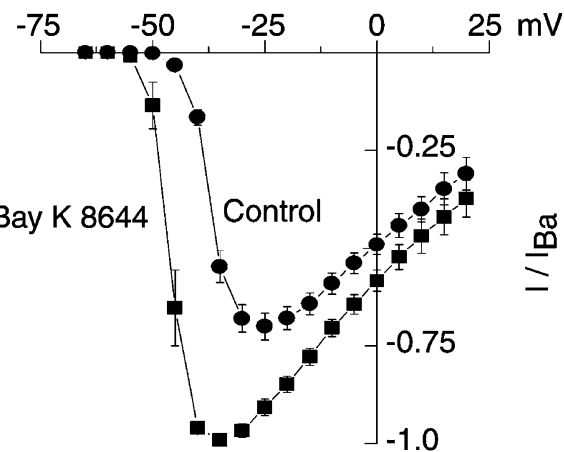
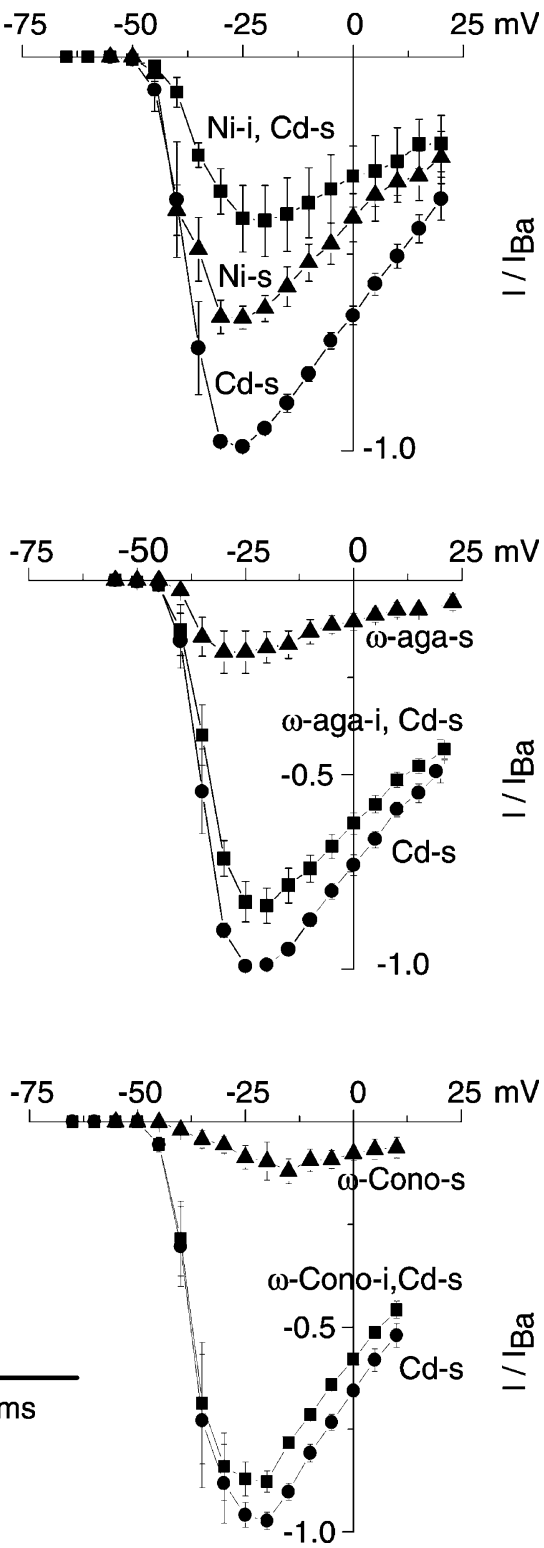

FIG. 6. Sensitivity to pharmacological agonists and antagonists indicate that most $\mathrm{I}_{\mathrm{Ba}}$ is mediated by L-type $\mathrm{Ca}^{2+}$ channels. Each of the subpanels on the left shows traces from an individual cell in $5 \mathrm{mM} \mathrm{Ba}^{2+}$ (control) and in the additional presence of a drug. In every experiment $0.4 \mathrm{mM}$ $\mathrm{Cd}^{2+}$ was applied after application of the drug so that the effects of drugs on the $\mathrm{Cd}^{2+}$-sensitive current could be assessed. Averaged results from measurements in three cells each are shown in the I/V plots on the right. A Inward currents in the presence of $5 \mathrm{mM} \mathrm{Ba}{ }^{2+}$ currents were enhanced by $10 \mu \mathrm{M}$ BAY K 8644, an agonist of L-type $\mathrm{Ca}^{2+}$ channels. B Most of the $\mathrm{I}_{\mathrm{Ba}}$ was sensitive to $150 \mu \mathrm{M}$ nifedipine, an antagonist of L-type calcium channels. C An antagonist of P/Q-type $\mathrm{Ca}^{2+}$ channels, $0.5 \mu \mathrm{M} \omega$-agatoxin IVA, blocked only a small fraction of $\mathrm{I}_{\mathrm{Ba}}$. D An antagonist of $\mathrm{N}$-type $\mathrm{Ca}^{2+}$ channels, $1 \mu \mathrm{M} \omega$-conotoxin GVIA, also blocked only a small fraction of $\mathrm{I}_{\mathrm{Ba}}$. 


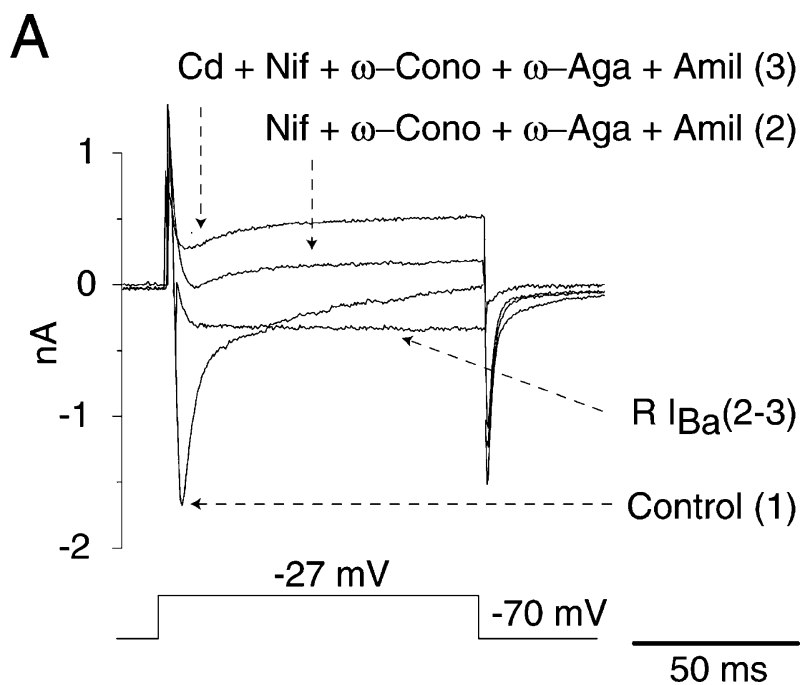

B

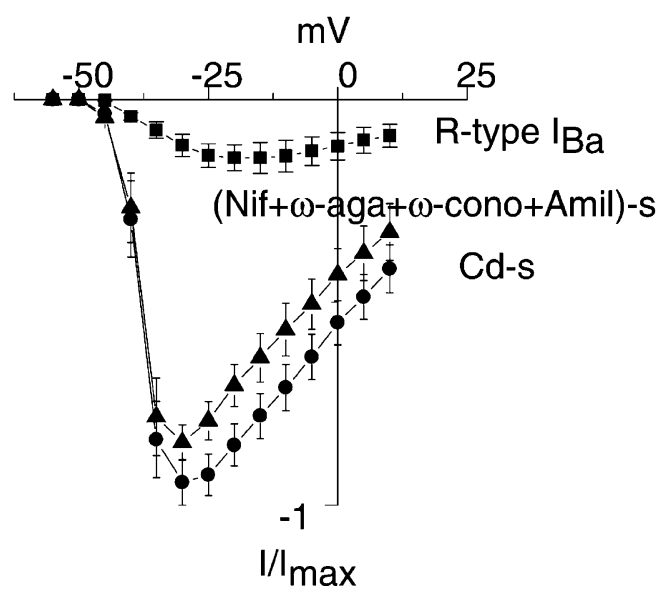

FIG. 7. A small fraction of the total $\mathrm{I}_{\mathrm{Ba}}$ was resistant to the combination of antagonists for $\mathrm{L}_{-}, \mathrm{N}-, \mathrm{P} / \mathrm{Q}-$, and T-type calcium channels. A Comparison of currents evoked by similar depolarizing voltage steps under various conditions: (1) control saline containing $5 \mathrm{mM} \mathrm{Ba}^{2+}$; (2) with $150 \mu \mathrm{M}$ nifedipine, $1 \mu \mathrm{M} \omega$-conotoxin GVIA, $0.5 \mu \mathrm{M} \omega$-agatoxin IVA, and $1 \mathrm{mM}$ amiloride; (3) with $0.4 \mathrm{mM} \mathrm{Cd}^{2+}$, $150 \mu \mathrm{M}$ nifedipine, $1 \mu \mathrm{M} \omega$-conotoxin GVIA, $0.5 \mu \mathrm{M} \omega$-agatoxin IVA, and $1 \mathrm{mM}$ amiloride; and (4) difference current (2-3) reveals the portion of the $\mathrm{Cd}^{+2}$-sensitive current that was resistant to the applied antagonists, $\mathrm{R} \mathrm{I}_{\mathrm{Ba}}$. B Voltage sensitivity of the R-type current recorded from three cells. The plot shows the total $\mathrm{Cd}^{+2}$-sensitive current (filled circle, 1-3), the current sensitive to the combination of $150 \mu \mathrm{M}$ nifedipine, $1 \mu \mathrm{M} \omega$-conotoxin GVIA, $0.5 \mu \mathrm{M} \omega$-agatoxin IVA, and $1 \mathrm{mM}$ amiloride (filled triangle, 1-2), and the R-type current that is sensitive to $\mathrm{Cd}^{2+}$ but insensitive to the more specific blockers (filled square, 2-3).

and Oertel 2006). The high-voltage-activated $\mathrm{K}^{+}$ conductance, $\mathrm{g}_{\mathrm{KH}}$, presumably contributes to rapid repolarization that allows octopus cells to fire at high frequencies (Bal and Oertel 2001; Macica et al. 2003). Coincident activation of small synaptic currents from large numbers of auditory nerve fibers depolarize the dendrites and cell bodies of octopus cells and can bring the axon to threshold (Golding et al. 1995; Golding et al. 1999).
Action potentials are conventional in that they are all-or-none and sensitive to TTX (Golding et al. 1995; Golding et al. 1999; Ferragamo and Oertel 2002). Voltage-gated $\mathrm{Ca}^{2+}$ currents will be activated by excitatory synaptic potentials and by regenerative $\mathrm{Na}^{+}$action potentials that depolarize octopus cells but those currents are small at the cell body. $\mathrm{I}_{\mathrm{Ca}}$ reaches maximally $1.1 \mathrm{nA}$ at $-23 \mathrm{mV}$; at this same voltage $\mathrm{I}_{\mathrm{KL}}$ is estimated to be about $30 \mathrm{nA}$ (Bal and Oertel 2001). Furthermore, $\mathrm{I}_{\mathrm{Ca}}$ is slow so that less than the maximal current would be expected to be activated by EPSPs or action potentials: at $-23 \mathrm{mV}$, $\mathrm{I}_{\mathrm{Ca}}$ reaches its peak about $5 \mathrm{~ms}$ after the onset of a square pulse of voltage whereas depolarizing responses to activation by the auditory nerve reach a peak within about $0.5 \mathrm{~ms}$. Being small relative to other voltage-sensitive currents and being slow relative to the duration of voltage changes in octopus cells, the contribution of voltage-gated $\mathrm{Ca}^{2+}$ currents to electrical signaling at the cell body is probably minor.

It is possible that the entry of calcium serves as a measure of activity and drives homeostatic mechanisms either at the cell body or elsewhere in octopus cells. L-type calcium channels are widespread, perhaps even ubiquitous, in the central nervous system and regulate protein phosphorylation, neuronal plasticity, and gene expression in neuronal cells (Murphy et al. 1991; Hell et al. 1993; Misra et al. 1994; Finkbeiner and Greenberg 1998). Calcium enters octopus cells not only through voltage-gated but also through ligand-gated receptors. Glutamate receptors in octopus cells do not contain GluR2 subunits and are calcium-permeable (Gardner et al. 1999; Gardner et al. 2001). The calcium from voltageand ligand-gated ion channels is likely to affect different locations, however. Octopus cells contain relatively high levels of the calcium-buffering protein, calretinin, which presumably localizes calcium transients to the vicinity of their sources (Adams 1997). Ltype calcium channels have the most rapid activation kinetics, the least voltage-dependent inactivation, and the most calcium-dependent inactivation of the highvoltage-activated calcium channels. Large EPSPs that signal the coincident firing of many auditory nerve fibers activate those L-type calcium channels and promote the entry of calcium. Whether they arise through activation of calcium-permeable glutamate receptors or L-type channels, high levels of calcium should inactivate the L-type channels and reduce further calcium entry.

\section{ACKNOWLEDGEMENTS}

We are grateful for the help and support of our colleagues Xiao-Jie Cao, Aldo Rodrigues, Shalini Shatadal, and Ravi 
Kochhar. An anonymous reviewer also made significant contributions. This work was supported by a grant from NIH DC00176.

\section{REFERENCES}

ADAms JC. Projections from octopus cells of the posteroventral cochlear nucleus to the ventral nucleus of the lateral lemniscus in cat and human. Auditory Neurosci. 3:335-350, 1997.

Bal R, Oertel D. Hyperpolarization-activated, mixed-cation current (Ih) in octopus cells of the mammalian cochlear nucleus. J. Neurophysiol. 84:806-817, 2000.

Bal R, Oertel D. Potassium currents in octopus cells of the mammalian cochlear nuclei. J. Neurophysiol. 86:2299-2311, 2001.

BEAN BP. Classes of calcium channels in vertebrate cells. Ann. Rev. Physiol. 51:367-384, 1989.

Boland LM, Morrill JA, Bean BP. $\omega$-Conotoxin block of N-type calcium channels in frog and rat sympathetic neurons. J. Neurosci. 14:5011-5027, 1994.

BRUEHL C, WADMAN WJ. Calcium currents in acutely isolated stellate and pyramidal neurons of rat entorhinal cortex. Brain Res. 816:554-562, 1999.

CaO X, Oertel D. Temperature affects voltage-sensitive conductances differentially in octopus cells of the mammalian cochlear nucleus. J. Neurophysiol. 94:821-832, 2005.

Carbone E, Lux HD. Kinetics and selectivity of a low-voltageactivated calcium current in chick and rat sensory neurones. J. Physiol. 386:547-570, 1987.

Carbone E, Swandulla D. Neuronal calcium channels: kinetics, blockade and modulation. Prog. Biophys. Mol. Biol. 54:31-58, 1989.

Coste B, Crest M, Delmas P. Pharmacological dissection and distribution of NaN/Nav1.9, T-type $\mathrm{Ca}^{2+}$ currents, and mechanically activated cation currents in different populations of DRG neurons. J. Gen. Physiol. 129:57-77, 2007.

Covey E, Casseday JH. The monaural nuclei of the lateral lemniscus in an echolocating bat: parallel pathways for analyzing temporal features of sound. J. Neurosci. 11:3456-3470, 1991.

Desmadryl G, Chambard JM, Valmier J, Sans A. Multiple voltagedependent calcium currents in acutely isolated mouse vestibular neurons. Neuroscience 78:511-522, 1997.

Desmadryl G, Hilaire C, Vigues S, Diochot S, Valmier J. Developmental regulation of T-, N- and L-type calcium currents in mouse embryonic sensory neurones. Eur. J. Neurosci. 10:545552, 1998.

Ferragamo MJ, Oertel D. Octopus cells of the mammalian ventral cochlear nucleus sense the rate of depolarization. J. Neurophysiol. 87:2262-2270, 2002.

FinKBEINER S, GREENBERG ME. $\mathrm{Ca}^{2+}$ channel-regulated neuronal gene expression. J. Neurobiol. 37:171-189, 1998.

Forscher P, OXFord GS. Modulation of calcium channels by norepinephrine in internally dialyzed avian sensory neurons. J. Gen. Physiol. 85:743-763, 1985.

Fox AP, Nowycky MC, Tsien RW. Kinetic and pharmacological properties distinguishing three types of calcium currents in chick sensory neurones. J. Physiol. (Lond) 394:149-172, 1987a.

Fox AP, Nowycky MC, Tsien RW. Single-channel recordings of three types of calcium channels in chick sensory neurones. J. Physiol. (Lond) 394:173-200, 1987b.

Gardner SM, Trussell LO, Oertel D. Time course and permeation of synaptic AMPA receptors in cochlear nuclear neurons correlate with input. J. Neurosci. 19:8721-8729, 1999.

Gardner SM, Trussell LO, Oertel D. Correlation of AMPA receptor subunit composition with synaptic input in the mammalian cochlear nuclei. J. Neurosci. 21:7428-7437, 2001.
Godfrey DA, Kiang NYS, Norris BE. Single unit activity in the posteroventral cochlear nucleus of the cat. J. Comp. Neurol. 162:247-268, 1975.

Golding NL, Robertson D, Oertel D. Recordings from slices indicate that octopus cells of the cochlear nucleus detect coincident firing of auditory nerve fibers with temporal precision. J. Neurosci. 15:3138-3153, 1995.

Golding NL, Ferragamo MJ, Oertel D. Role of intrinsic conductances underlying responses to transients in octopus cells of the cochlear nucleus. J. Neurosci. 19:2897-2905, 1999.

Hell JW, Westenbroek Re, Warner C, Ahljanian MK, Prystay W, Gilbert MM, Snutch TP, Catterall WA. Identification and differential subcellular localization of the neuronal class $\mathrm{C}$ and class D L-type calcium channel alpha 1 subunits. J. Cell. Biol. 123:949-962, 1993.

Hess P, Lansman JB, Tsien RW. Different modes of Ca channel gating behaviour favoured by dihydropyridine $\mathrm{Ca}$ agonists and antagonists. Nature 311:538-544, 1984.

Hille B. Ion Channels of Excitable Membranes. Sunderland: Sinauer Associates, 2001.

Ikeda M, Матsumoto S. Classification of voltage-dependent $\mathrm{Ca}^{2+}$ channels in trigeminal ganglion neurons from neonatal rats. Life Sci. 73:1175-1187, 2003.

Kanngiesser U, Nalik P, Pongs O. Purification and affinity labeling of dihydropyridine receptor from rabbit skeletal muscle membranes. Proc. Natl. Acad. Sci. U S A 85:2969-2973, 1988.

Li YW, GuYenet PG, Bayliss DA. Voltage-dependent calcium currents in bulbospinal neurons of neonatal rat rostral ventrolateral medulla: modulation by $\alpha 2$-adrenergic receptors. J. Neurophysiol. 79:583-594, 1998.

Lipscombe D, Pan JQ, Gray AC. Functional diversity in neuronal voltage-gated calcium channels by alternative splicing of $\mathrm{Ca}_{\mathrm{V}} \alpha 1$. Mol. Neurobiol. 26:21-44, 2002.

Lipscombe D, Helton TD, Xu W. L-type calcium channels: the low down. J. Neurophysiol. 92:2633-2641, 2004.

Luhmann HJ, Reiprich RA, Hanganu I, Kilb W. Cellular physiology of the neonatal rat cerebral cortex: intrinsic membrane properties, sodium and calcium currents. J. Neurosci. Res. 62:574-584, 2000.

Macica CM, von Hehn CA, Wang LY, Ho CS, Yokoyama S, Joho RH, KaczmareK LK. Modulation of the kv3.1b potassium channel isoform adjusts the fidelity of the firing pattern of auditory neurons. J. Neurosci. 23:1133-1141, 2003.

Martinez-Pinna J, Lamas JA, Gallego R. Calcium current components in intact and dissociated adult mouse sympathetic neurons. Brain Res. 951:227-236, 2002.

McCleskey EW, Fox AP, Feldman DH, Cruz LJ, Olivera BM, Tsien RW, Yoshikami D. Omega-conotoxin: direct and persistent blockade of specific types of calcium channels in neurons but not muscle. Proc. Natl. Acad. Sci. U S A 84:4327-4331, 1987.

McGinley MJ, Oertel D. Rate thresholds determine the precision of temporal integration in principal cells of the ventral cochlear nucleus. Hear. Res. 216-217:52-63, 2006.

McGinley MJ, Lazimy YM, Bal R, Oertel D. Measurement and modeling of cable properties and optimal input delay profiles in octopus cells of the ventral cochlear nucleus. Ass. Res. Otolaryngol. Abstr. 28:2005.

Mintz IM, Adams ME, Bean BP. P-type calcium channels in rat central and peripheral neurons. Neuron 9:85-95, 1992.

Misra RP, Bonni A, Miranti CK, Rivera VM, Sheng M, Greenberg ME. L-type voltage-sensitive calcium channel activation stimulates gene expression by a serum response factor-dependent pathway. J. Biol. Chem. 269:25483-25493, 1994.

Mouginot D, Bossu JL, Gahwiler BH. Low-threshold $\mathrm{Ca}^{2+}$ currents in dendritic recordings from Purkinje cells in rat cerebellar slice cultures. J. Neurosci. 17:160-170, 1997. 
Murphy TH, Worley PF, Baraban JM. L-type voltage-sensitive calcium channels mediate synaptic activation of immediate early genes. Neuron 7:625-635, 1991.

Oertel D, Wickesberg RE. Ascending pathways through the ventral nuclei of the lateral lemniscus and their possible role in pattern recognition in natural sounds. In: Oertel D, Fay RR and Popper AN (eds) Integrative Functions in the Mammalian Auditory Pathway. New York, Springer Verlag, pp. 207-237, 2002.

Oertel D, Wu SH, Garb MW, Dizack C. Morphology and physiology of cells in slice preparations of the posteroventral cochlear nucleus of mice. J. Comp. Neurol. 295:136-154, 1990.

Oertel D, Bal R, Gardner SM, Smith PH, Joris PX. Detection of synchrony in the activity of auditory nerve fibers by octopus cells of the mammalian cochlear nucleus. Proc. Nat. Acad. Sci. U S A 97:11773-11779, 2000.

Osen KK. Cytoarchitecture of the cochlear nuclei in the cat. J. Comp. Neurol. 136:453-484, 1969.

Overholt JL, PrabhakAR NR. $\mathrm{Ca}^{2+}$ current in rabbit carotid body glomus cells is conducted by multiple types of high-voltageactivated $\mathrm{Ca}^{2+}$ channels. J. Neurophysiol. 78:2467-2474, 1997.

RANDALl A, TSIEN RW. Pharmacological dissection of multiple types of $\mathrm{Ca}^{2+}$ channel currents in rat cerebellar granule neurons. J. Neurosci. 15:2995-3012, 1995.

REgAN LJ, SAH DW, BEAN BP. Ca ${ }^{2+}$ channels in rat central and peripheral neurons: high-threshold current resistant to dihydropyridine blockers and omega-conotoxin. Neuron 6:269-280, 1991.

RHODE WS. Temporal coding of $200 \%$ amplitude modulated signals in the ventral cochlear nucleus of cat. Hear. Res. 77:43-68, 1994.

RHODE WS. Neural encoding of single-formant stimuli in the ventral cochlear nucleus of the chinchilla. Hear. Res. 117:39-56, 1998.

Rhode WS, Smith PH. Encoding timing and intensity in the ventral cochlear nucleus of the cat. J. Neurophysiol. 56:261-286, 1986.

Rhode WS, Oertel D, Smith PH. Physiological response properties of cells labeled intracellularly with horseradish peroxidase in cat ventral cochlear nucleus. J. Comp. Neurol. 213:448-463, 1983.
Scamps F, Valentin S, Dayanithi G, Valmier J. Calcium channel subtypes responsible for voltage-gated intracellular calcium elevations in embryonic rat motoneurons. Neuroscience 87:719-730, 1998.

SCHOFIELD BR. Projections from the cochlear nucleus to the superior paraolivary nucleus in guinea pigs. J. Comp. Neurol. 360:135-149, 1995

SLESINGER PA, LANSMAN JB. Inactivation of calcium currents in granule cells cultured from mouse cerebellum. J. Physiol. (Lond) 435:101-121, 1991.

Smith PH, Joris PX, Banks MI, YIN TCT. Responses of cochlear nucleus cells and projections of their axons. In: Merchan MA, Juiz JM, Godfrey DA, Mugnaini E (eds) The Mammalian Cochlear Nuclei, Organization and Function. New York, Plenum Press, pp. 349-360, 1993.

Smith PH, MAssie A, Joris PX. Acoustic stria: anatomy of physiologically characterized cells and their axonal projection patterns. J. Comp. Neurol. 482:349-371, 2005.

Tsien RW, Lipscombe D, Madison DV, Bley KR, Fox AP. Multiple types of neuronal calcium channels and their selective modulation. Trends Neurosci. 11:431-438, 1988.

Vater M, Covey E, Casseday JH. The columnar region of the ventral nucleus of the lateral lemniscus in the big brown bat (Eptesicus fuscus): synaptic arrangements and structural correlates of feedforward inhibitory function. Cell Tissue Res. 289:223233, 1997.

WARR WB. Fiber degeneration following lesions in the posteroventral cochlear nucleus of the cat. Exp. Neurol. 23:140-155, 1969.

Wicher D, Penzlin H. $\mathrm{Ca}^{2+}$ currents in central insect neurons: electrophysiological and pharmacological properties. J. Neurophysiol. 77:186-199, 1997.

Willott JF, Bross LS. Morphology of the octopus cell area of the cochlear nucleus in young and aging C57BL/6J and CBA/J mice. J. Comp. Neurol. 300:61-81, 1990.

Xu W, Lipscombe D. Neuronal Ca(V)1.3alpha(1) L-type channels activate at relatively hyperpolarized membrane potentials and are incompletely inhibited by dihydropyridines. J. Neurosci. 21:5944-5951, 2001. 